\title{
PĚT TEZí SOUČASNÉ KULTURNÍ EKOLOGIE
}

\author{
MILOSLAV LAPKA, ZDENKA SOKOLÍČKOVÁ a JAN VÁVRA
}

\begin{abstract}
Úvod
Kulturní ekologie rozhodně není tradiční pevně zakotvenou vědeckou disciplínou, ani $\mathrm{v}$ českém prostředí, ani ve světě. $V$ současné době je to široce pojatý proud empirických studií a myšlení inspirovaného př́stupy ekologie, antropologie a tématy kulturálních studií. Také v našem pojetí je současná kulturní ekologie více př́stupem než striktně vymezenou disciplínou. Díky své paradigmatické otevřenosti má však potenciál oslovit různé obory a vyjádřit se $\mathrm{k}$ aktuálním problémům. Než se pokusíme nastínit pět základních tezí současné kulturní ekologie, absolvujeme v úvodu krátký exkurz do historie oboru a do dalších zdrojů inspirace současného pojetí. Na to naváže stručný výčet pracovišt a osobností českého akademického prostředí, jejichž činnost se dotýká předmětu zájmu kulturní ekologie. Poté bude následovat již zmiňovaných pět aktuálních tezí. Závěr poslední teze tvoří i závěr celého článku.
\end{abstract}

\section{Kořeny a inspirace současné kulturní ekologie}

\section{Klasická kulturní ekologie}

Kulturní ekologie bývá obvykle spojována se jménem zakladatele Juliana Stewarda (1902-1972) a jeho dílem, které se stalo synonymem kulturní ekologie - Theory of Culture Change: The Methodology of Multilinear Evolution z roku 1955. Julian Steward byl empiricky zaměřeným antropologem, jdoucím po faktech více než po rozsáhlých teoriích. Tím se ubránil environmentálnímu determinismu, stejně jako výrazné preferenci technologie získávání energie, kterou nalézáme v teoretických úvahách Leslieho Whitea [White 1959], a stejně tak se ubránil radikálním tezím uni-lineární kulturní evoluce Lewise Henryho Morgana [Morgan 1954]. Hlavně však ponechal otevřené dveře pro multilineární možnosti kulturní adaptace na změny př́rodních podmínek. ${ }^{1}$

Studium ekologie, ekologických podmínek, ekosystémů a jejich spojování se změnami společnosti je zřejmě vůbec prvním a zakládajícím rysem kulturní ekologie. Ze

1 Stewardova teorie multilineární evoluce zdůrazňuje vliv prostředí na vývoj kultury. Kulturní evoluce tak postupuje po různých liniích $\mathrm{v}$ různých společnostech a prostředích. Tato teorie je v protikladu ke starší klasické evolucionistické teorii, která předpokládá, že všechny kultury procházejí stejnými vývojovými stadii [srov. Steward 1955]. 
základního díla Theory of Culture Change uved’me alespoň jednu citaci, která ilustruje, co zde bylo řečeno: „(kulturní ekologie je) ... metoda pro rozpoznání způsobů, jimiž je kulturní změna vyvolaná adaptací na prostředí“ [Steward 1955: 5]. Kulturní ekologie tedy rozpoznává a popisuje způsob, jakým se kultura přizpůsobuje změnám v prostředí, a to zkoumáním mechanismu kulturní změny (culture change).

Kulturní změna jako odezva společnosti na tlaky prrírodního prostředí nepřináší jen preferenci environmentálních faktorů v porovnání s kulturními, ale také pohled na společnost jako součást většího př́ŕrodního (ne-humánního) ekosystému, což je pohled, který na konci minulého století dosáhl velkého rozmachu např́klad v ekologické etice, v hypotéze Gaia i v nejrůznějších podobách environmentálních hnutí jako například New Age.

Nutno podotknout, že Julian Steward své první poznatky o vlivu prrírodního prostř̌edí na změny studované kultury formuloval před rokem 1955 ve dvou studiích z roku 1950 a 1951 [Steward 1950, 1951].

Důležitost ekologických faktorů pro kulturní změnu je charakteristickým pokračováním kulturní ekologie v tradičním, antropologickém, pojetí, a jak uvádíme v našich pěti tezích, také pro kulturní ekologii přítomnou, pro kulturní ekologii tak, jak by mohla potenciálně nabízet svá metodologická i praktická řešení pro současné globální problémy společnosti.

V osobě zakladatele Juliana Stewarda získala kulturní ekologie interdisciplinární pohled, který je její další charakteristikou. Pohled balancující mezi kulturologií, at už ji vymezujeme jako vědu o kultuře nebo jako kulturální studia (cultural studies), a ekologií. Je jeho zásluhou, že nezavřel ani kulturní, ani ekologické dveře radikálními tezemi vylučujícími jedno nebo druhé.

Takto ve zkratce vymezená kulturní ekologie ukazuje, o jak extrémně široké pojetí jde. Není divu. Máme co do činění ve filosofickém smyslu se vztahy člověka a přírody, ve smyslu kulturní ekologie se vztahy kultury a přírodního prostředí. To někdy vede $\mathrm{k}$ rezignaci a kritice, co vlastně kulturní ekologie je, co kulturní ekologie není a co má být. Robert $M$. Netting přes veškerou kritiku názvu a širokého pojetí nakonec konstruktivně prohlašuje: „Je jediný způsob jak vysvětlit, co to je kulturní ekologie: ukázat, čím se zabývá“ [Netting 1968: 6]. Sebe-reflexe kulturní ekologie je její překvapivě silnou stránkou př̀ vytváření tohoto nového paradigmatu a zřejmě překračuje období „pubertální (premature) nezralosti“. Je znakem životaschopnosti a doposud nevyčerpaného potenciálu a překračuje nejen hranice pubertální nezralosti, ale také hranice relativně uzavřených a současné civilizaci vzdálených kultur. ${ }^{2}$

Nettingovo prohlášení o jediném způsobu jak vysvětit, co je kulturní ekologie, tím, že ukážeme, co dělá, se do určité míry stalo návodem k pěti tezím. Tématy, co a jak kulturní ekologie dělá nebo naopak nedělá, jsou naplněny další články v tomto vydání Acta Universitatis Carolinae Philosophica et Historica. ${ }^{3}$ My se soustředíme na to, co by mohla dělat a jaké jsou její základní teze.

2 Z významných představitelů kulturní ekologie uved’me alespoň neúplným výčtem tato jména: Marshall D. Sahlins, Robert M. Netting, Roy A. Rappaport, John W. Bennet, Andrew P. Vayda, Bonne J. McCay, David J. Damas, James Anderson a Tom E. Fricke.

3 Tento článek je přepracovaným úvodním př́íspěvkem „Naše společná přítomnost: Globální výzvy pro kulturní a sociální ekologii, “ který byl přednesen na stejnojmenné konferenci pořádané na Katedře teorie kultury (kulturologie) Filozofické fakulty Univerzity Karlovy v Praze 2. března 2011. I další články byly bud’ předneseny na konferenci, nebo byly shromážděny při této př́ležitosti. 


\section{Dvojí sociální ekologie}

Díky širokému tematickému záběru kulturní ekologie se v našem akademickém prostředí často spojuje kulturní ekologie dohromady se sociální ekologii. ${ }^{4}$ Je však vhodné jasně odlišit kořeny obou př́istupů a jejich souvislosti. Obecně můžeme říci, že kulturní ekologie je snaha o ekologickou reflexi kultury a sociální ekologie je snaha o ekologickou reflexi společnosti. Klasickou kulturní ekologii jakožto antropologickou disciplínu jsme již představili. Se sociální ekologií je to trochu složitější. Tento pojem používají dva směry, které se od sebe velmi odlišují. Jedním je aktivistická sociální ekologie Murraye Bookchina, druhým pak sociální ekologie města navazující na chicagskou Human ecology.

Americký filosof a anarchista Mumford Gutkind (Murray) Bookchin (1921-2006) byl jedním z prvních autorů, kteř́ již v 50 . letech 20 . století poukazovali na problémy životního prostředí spojené $s$ rychlým hospodářským růstem. Environmentální problémy jsou podle jeho sociální ekologie odrazem sociálních problémů a společenské hierarchie [Bookchin 2005]. Bookchinovi i jeho následovníkům, sdruženým okolo Institute for Social Ecology ve Vermontu v USA, který Bookchin v roce 1974 založil, byl a je vlastní radikální sociální aktivismus. Nešlo (a nejde) jen o vědecký popis společnosti, ale především o její změnu s důrazem na anarchismus, spontaneitu a decentralizaci. ${ }^{5}$

Sociální ekologie navazující na chicagskou sociologickou školu a její Human ecology se velmi liší od výše zmíněné Bookchinovy sociální ekologie. Její vznik je spojen se jmény Robert Ezra Park (1864-1944), Roderick Duncan McKenzie (1885-1940) a Ernest Watson Burgess (1886-1966) a nejznámější prací je sborník The City [Park, McKenzie, Burgess 1925]. Human ecology se inspirovala systémovostí ekologie a její terminologií a pokusila se tento př́stup aplikovat na studium rychle rostoucího Chicaga první poloviny 20. století [Park 1915]. Důraz je kladen na komunitu, její organizaci [Park 1936] a především prostorové uspořádání komunity [McKenzie 1924]. Sociální ekologie ve druhé polovině 20. století nezpochybnila základní orientaci danou chicagskou školou, tedy snahu o systémovou a prostorově orientovanou sociologii města [srov. Musil 1992]. I přesto se ale chicagská Human ecology dočkala kritiky z různých stran, ze strany přímých následníků pro nedostatečné propracování ekologické metodiky [Hawley 1944], v současnosti pak proto, že redukovala ekologické jevy spíše na jevy geografické, o kulturních jevech nemluvě, a plna dobového optimismu nebrala v úvahu ekologické limity prostředí [srov. Keller 1997: 50-65].

Oba proudy odlišné sociální ekologie mohou být pro současnost inspirací, první Bookchinova - tím, že nerezignuje na společenskou angažovanost (byt je pro vědce chtějícího si udržet jistou míru nezávislosti až př́liš aktivistická a hraničí s anarchismem).

4 Budeme-li dále hovořit o našem pojetí současné kulturní a sociální ekologie, budeme používat pouze termín (současná) kulturní ekologie. Když budeme odkazovat na původní kulturní ekologii Juliana Stewarda, bude to vždy jasně řečeno.

5 Více o cílech a názorech sociálně ekologického hnutí viz web http://www.social-ecology.org/. Česky vyšla kniha Bookchinovy blízké spolupracovnice Janet Biehl [Biehl 2003].

6 Naopak, rozvoj technologie a především dopravy jsou vnímány jako jednoznačně pozitivní ekologické faktory. Tento postoj zastává i zástupce další generace Human ecology Amos Henry Hawley (1910-2009) [srov. Keller 1997]. Keller také poukazuje na zajímavý (těžko říci, zda zamýšlený) fakt, že se chicagská škola snažila nejen porozumět dynamickým procesům velkoměsta, ale svou pozitivní interpretací je i legitimizovat [ibid.]. 
Druhá - s kořeny v Human ecology - inspiruje především systémovým přístupem ke studiu společnosti a jejího prostředí (ovšem nese v sobě memento nebezpečí př́lišné redukce kulturních jevů na ekologické i ekologických na geografické). I přes pozdější kritiku jsou oba směry důležité tím, že přispěly $\mathrm{k}$ respektování provázanosti lidského života a okolního prostředí, jež má zásadní vliv na kvalitu lidského života.

\section{Environmentální sociologie}

Novějším z důležitých společenskovědních směrů 20. století, který inspiruje současnou kulturní ekologii, je environmentální sociologie. Environmentální sociologii ustanovili na konci 70. let američtí sociologové William Catton Jr. ( $\left.{ }^{\star} 1926\right)$ a Riley E. Dunlap $\left({ }^{\star} 1943\right)$ jako opozici proti převažujícímu sociologickému paradigmatu, které při studiu společnosti nebere dostatečně v úvahu jiné než společenské faktory. Toto klasické paradigma, projevující se v různých teoretických a empirických podobách sociologie, nazvali Catton a Dunlap Paradigmatem lidské výjimečnosti, známým často pod anglickou zkratkou $\mathrm{HEP}^{7}$ (Human Exemptionalism Paradigm) [Dunlap, Catton 1979]. Za „původce“ tohoto HEP př́stupu byl jimi označován Émile Durkheim, především kvůli svému dílu Pravidla sociologické metody, ve kterém kladl důraz na sociální vysvětlení sociálních faktů namísto reduktivních ${ }^{8}$ vysvětlení [Durkheim 1966]. Antropocentrismus a zdánlivě neomezené možnosti konce 19. a první poloviny 20. století dávaly paradigmatu HEP zelenou. Proti tomu staví Catton a Dunlap Nové ekologické paradigma, známé pod zkratkou NEP (New Ecological Paradigm), které bere v úvahu vnější, mimospolečenské vlivy.

Environmentální sociologie s sebou přináší uznání toho, že fyzické prostředí může ovlivňovat lidské společnosti a chování (a následně jimi být ovlivňováno). Environmentální sociologové tudíž upouštějí od tradičního sociologického trvání na tom, že sociální fakty mohou být vysvětleny pouze jinými sociálními fakty. [Dunlap, Catton 1979: 244]

Environmentální sociologie je inspirací pro současnou kulturní ekologii především díky uznání vzájemných vazeb člověka a jeho prostředí, což samozřejmě platí i v současných moderních komplexních společnostech, i když prostředí - environment - si společnost přetváří do často dříve netušených globálních rozměrů (klasická kulturní ekologie se jakožto antropologická věda orientovala spíše na méně složité společnosti a skupiny).

\footnotetext{
7 V literatuře se také někdy uvádí zkratka DSP - Dominant Social Paradigm. Jak HEP, tak DSP označují paradigmata výjimečnosti a nezávislosti lidského sociálního systému na prostředí, převažující v sociologickém myšlení a kritizovaném environmentálními sociology.

8 Doslova piśí o „antiredukcionistickém tabu“ [Catton, Dunlap 1980: 19]. Toto „obviňování“ Durkheima zpochybňují ve své práci Eugene A. Rosa a Lauren Richter [Rosa, Richter 2008] s odkazem na jeho úvodní přednášku ke kurzu sociálních věd v letech 1887-1888 na univerzitě v Bordeaux [Durkheim 2008].
} 


\section{Kulturní a sociální ekologie v českém akademickém prostředí}

Článek jsme začali tvrzením, že kulturní a sociální ekologie není ani v českém akademickém prostředí pevně zakotvenou disciplínou. To ale neznamená, že by byla disciplínou zcela neznámou. Kulturní či sociální ekologií se zabývá (nebo zabývalo) několik pracoviš̉ a několik významných autorů9. Pokusme se je sledovat chronologicky, i když se jejich osudy budou proplétat.

Autorem, který není trvale spojen s jediným pracovištěm, je urbánní sociolog Jiř́ Musil ( $\left.{ }^{\star} 1928\right)$. Již od 60 . let se věnuje problematice sociologie města a sociologie bydlení. Je zástupcem prostorově a městsky orientované sociální ekologie [Musil 1992].

Další z výrazných postav české sociální ekologie je Bohuslav Blažek (1942-2004). Jeho pojetí sociální ekologie zdůrazňuje především neustálou reflexi vlastního jednání a reflexi prostředí ve velmi širokém smyslu [Blažek 1998]. Na rozdíl od sociální ekologie města se Bohuslav Blažek zaměřoval (především po roce 1989) více na problematiku venkova. Bohuslava Blažka a Miloslava Lapku ( $\left.{ }^{*} 1957\right)$, dalšího z autorů zabývajícího se dlouhodobě kulturní či sociální ekologií, spojovalo jejich pracoviště, tedy Ústav krajinné ekologie ČSAV, ${ }^{10}$ přejmenovaný v roce 1993 na Ústav ekologie krajiny AV ČR. Miloslav Lapka ve své práci věnuje velkou pozornost venkovu, zemědělství a kulturní krajině [Lapka, Gottlieb 2000; Lapka 2008].

Další z osobností, kterou je třeba zmínit, je sociolog Jan Keller ( $\left.{ }^{\star} 1955\right)$, jenž se dlouhodobě věnuje environmentální problematice a vztahu sociologie a ekologie [např. Keller 1997; Keller 1998].

Kulturní a sociální ekologie je od roku 1995 vyučována na Katedře teorie kultury (kulturologie) Filozofické fakulty Univerzity Karlovy v Praze. ${ }^{11}$ Pod dlouhodobým vedením Jitky Ortové $\left({ }^{\star} 1946\right)$ se orientovala především na kulturologickou reflexi ekologické krize a zmapování velmi širokého proudu ekologicky relevantní literatury. Interpretační rámec vycházel z pojetí kultury jako adaptace Juliana Stewarda [Ortová 1997]. V současnosti prochází koncepce kulturní ekologie na této katedře změnami, které jsou čtenářmm předkládány v tomto a dalších článcích [Lapka, Vávra, Sokolíčková 2011].

Od roku 1998 existuje Katedra environmentálních studií na Fakultě sociálních studií Masarykovy univerzity v Brně, kde se vyučuje obor Environmentální studia, přistupující k současné ekologické krizi z pohledu humanitních věd. Vznik oboru i jeho existence je spojen především se jménem Hany Librové $\left({ }^{*} 1943\right)$, environmentálně orientované socioložky [např. Librová 1987; Librová 1994].

9 Cílem článku není podat podrobný přehled o všech českých akademických pracovištích, které přistupují k problémům životního prostředí z pohledu společenských věd. To by vydalo na samostatný článek. V této části zmiňujeme pouze několik vybraných pracovišt a autorů, kteří se věnovali př́mo kulturní a sociální ekologii či komplexně humanitnímu přístupu k environmentálním problémům. Stranou tak zůstává mnoho zajímavých institucí (např. Centrum pro otázky životního prostředí Univerzity Karlovy v Praze) i individualit. Zde za všechny jmenujme Pavla Nováčka z Univerzity Palackého v Olomouci, jenž se dlouhodobě věnuje problematice udržitelného rozvoje.

${ }_{10} \mathrm{~V}$ tomto ústavu vzniklo $\mathrm{v} 70$. letech oddělení věnující se člověku i z pohledu humanitních věd. Jelikož nebylo možné používat tradiční názvy známé ze Západu (ekologie člověka, humánní ekologie, sociální ekologie) byl vynalezen název antropoekologie [Blažek 1998: 25]. Tento název se na pracovišti používal ještě dlouho po roce 1989.

11 Více o oboru kulturologie viz práce Václava Soukupa [Soukup 2010; Soukup 2011]. 
Poslední z environmentálně orientovaných společenskovědních univerzitních pracovišt co do data založení je Katedra sociální a kulturní ekologie Fakulty humanitních studií Univerzity Karlovy v Praze. Založena byla v roce 2000 a orientuje se především na různé aspekty trvale udržitelného rozvoje i praktické nástroje k jeho realizaci. Jejím zakladatelem a vedoucím je Ivan Rynda ( $\left.{ }^{*} 1953\right)$, jenž se věnuje právě trvale udržitelnému rozvoji [např. Rynda 2006].

Jak vidno, pracoviště a autoři zabývající se environmentální problematikou z pohledu společenských věd se od sebe dosti odlišují. Tuto pluralitu a nezakotvenost (která existuje v českém i zahraničním prostředí) můžeme brát bud' jako nedostatek, nebo naopak jako pozitivum, umožňující různost pohledů na jednotlivé problémy. Spolu s Bohuslavem Blažkem preferujeme jednoznačně tento pozitivní pohled:

Sociální ekologie je vědní obor, který má tolik tváří, kolik pracovišt’ a v krajním případě kolik badatelů se jím zabývá. Narozdíl od příbuzné (celkově více biologicky laděné) humánní ekologie tento obor nepořádá mezinárodní konference ani nevydává mezinárodní časopis. Všechna nejznámější pracoviště, v Irvine (Kalifornie), Frankfurtu nad Mohanem, Hawkesbury (Západní Sydney) nebo - pro svou ideologičnost pro mě nepřijatelné - v Plainfieldu (Vermont), dělají, jako kdyby existovalo jen to jejich... Takto popsána se sociální ekologie může jevit jako trapný chaos. Na druhé straně lze říci, že v ní panuje mimořádná pluralita a většina jejích stoupenců přispívá k rodícímu se vědnímu paradigmatu daleko důsledněji než kterákoli jiná mně známá věda. Reflexe zodpovědného počínání odborníka je její zásadní součástí. [E-Architekt 2004]

\section{Pět tezí současné kulturní ekologie}

Pokusme se nyní formulovat požadavky na disciplínu současné kulturní ekologie ve světle současných výzev a obtíží, na které veřejnost, včetně té odborné, musí brát zřetel. Nemá se jednat o manifest volající po zcela nových přístupech, nebot programová prohlášení takového typu málokdy vedou k nějakým cílům, kromě chronického zatuhnutí ve vlastní nenaplnitelné programovosti. Usilujeme spíše o to poukázat na výzvy, před kterými současná kulturní ekologie dnes stojí a které má možnost uchopit, najde-li se dost kulturních ekologů ochotných vyslovovat se k aktuálním problémům.

\section{Teze 1. Zaměření na př́tomnost}

Když byla v roce 1987 vydána zpráva Naše společná budoucnost Světové komise pro životní prostředí a rozvoj, živá diskuse nad problematikou životního prostředí devastovaného v důsledku neudržitelných životních strategií vyspělých zemí už za sebou měla více než dvě dekády.

Orientace na budoucnost, kterou se analýzy a studie zcela oprávněně vyznačují, a kterou kritici nepřiměřeně zdůrazňují, ale s sebou nese jeden nepříznivý aspekt. Volání po změně $\mathrm{v}$ zájmu budoucnosti má mizivou účinnost a nízký potenciál iniciovat skutečnou proměnu vzorců spotřeby či vztahování se k přírodnímu světu z pozice zástupce 
západního světa. Vizionářské snahy a velké projekty předefinování místa člověka v přírodě provokují ke kritice, která je populistická, avšak zároveň stojí na reálném základě - požadavku řešení současných tíživých problémů. Ve svém anti-environmentálním a anti-ekologistickém tažení toho s publicistickou lehkostí využil také současný prezident České republiky, Václav Klaus, když ve svém novoročním projevu z roku 2010 pronesl tato slova:

Nežijeme z jakékoli benevolence minulých generací a zatím nic nedlužíme generacím budoucím. Jediné, co bychom jim mohli dlužit, by bylo to, kdybychom po sobě nezanechali svobodnou a prosperující společnost. Právě v tomto smyslu dělejme dnes, zítra, pozítří to nejlepší, co umíme. Co bude za 100 let, nechme spisovatelům sci-fi literatury. Zůstaňme oběma nohama na zemi a starejme se o to, co nám přísluší. Je toho více než dost. [Klaus 2010] ${ }^{12}$

Závazek vůči budoucím generacím, který je součástí definice trvale udržitelného rozvoje, jak jej představuje právě Brundtlandové zpráva ${ }^{13}$, se v tomto podání zdá být nelegitimním a tedy nežádoucím. A ve chvíli, kdy je zpochybněna legitimita tak závažné výzvy, jako je revize vztahu člověka (kultury, společnosti) k životnímu prostředí ve prospěch budoucnosti, hrozí netečnost těch, kteří by mohli jednat nyní. Otázek přítomnosti přitom skutečně není málo: od hladu, zotročujících ideologií až po ničení životního prostředí a redukci člověka na součást jím vytvořených systémů. Kulturní ekologie může, či alespoň my jsme o tom přesvědčeni, že by měla, přispět k aktualizaci uvažování o př́rodním světě ve společenských vědách a zbavit naopak oprávněnosti každý pokus o upevnění neoliberálního alibismu.

Není to však jen obrat k budoucnosti, který může vědám o člověku a př́rodě uškodit. Ještě úpornějším a hůře odstranitelným nešvarem je posedlost oborovou historií. Spíše než nové interpretace toho, co již bylo vysloveno, tu máme na mysli opakované inventury vlastního dědictví, někdy přerůstající v jakési mantry, které mají posloužit jako ospravedlnění místa v akademickém prostoru. Emanuel Adler, profesor mezinárodních vztahů na univerzitě v Torontu, nabádá k tomu, aby civilizace jakožto společenské konstrukty byly posuzovány na základě svých činů a nikoliv podle toho, co o sobě prohlašují [Adler 2010]. Nestačí tedy umně představené bohaté dějiny a deklarace vznešeného úmyslu, at už se jedná o hráče na poli mezinárodních vztahů nebo o společenské vědy. Ani výhradní orientace na minulost neosvětluje současné problémy v interakci člověk (společnost)-kultura-prostředí.

Zaměření na př́itomnost je zde motivováno potřebou neodsoudit současný stav věcí jako jakési strukturální provizorium, ale naopak jej přijmout coby výsadní předmět zá-

12 V projevu je dále uvedeno: „Nemůžeme vědět, kolik - kvůli nim - smíme spotřebovat dnes známých a dostupných přírodních zdrojů.... A budou vůbec námi dnes eventuálně ušetřené zdroje potřebovat?" [Klaus 2010] Několik dekád před položením otázky ji zodpověděl britský morální a politický filosof Brian Barry: „Samožrejmě nevíme, jaký přesně bude vkus našich vzdálených potomků, ale je nepravděpodobné, že by zahrnoval zálibu v rakovině kůže, erozi půdy nebo zaplavení nízko položených oblastí v důsledku tání ledovcü“ [cit. dle Attfield 1991: 98].

13 Trvale udržitelný rozvoj je takový způsob rozvoje, který uspokojuje potřeby př́itomnosti, aniž by oslaboval možnosti budoucích generací naplňovat jejich vlastní potřeby. [United Nations 1987] 
jmu. Přítomnost jako to, na čem záleží nejvíce, a jako jediná možná sféra výzkumu, skrze niž se kulturní a sociální ekologie může emancipovat od neurčitého proroctví i historiografické repetice bez aktuálního přesahu.

\section{Teze 2. Transdiciplinarita}

Vedle pasti, kterou je pro kulturní a sociální ekologii zájem o minulost či budoucnost bez skutečné vazby na stávající problémy, existuje další úskalí této disciplíny, a to její vědecká metoda, lépe řečeno absence takové metody či její neurčitost.

Dnešní společenskovědní diskurs zachází s pojmy jako interdisciplinarita či multidisciplinarita s lehkostí, která dává tušit, že jsou tyto koncepty považovány za všeobecně známé a funkční. Naše druhá teze chce tuto domněnku problematizovat. Nejprve je však nutné objasnit terminologické rozdíly mezi výrazy, které jsou někdy nesprávně užívány jako synonyma.

Interdisciplinarita, neboli způsob kooperace různých vědních disciplín, může nabývat tří různých podob [Baumgärtner 2008].

První z nich, v níž jednotlivé nauky pracují na stejném úkolu za užití vlastních termínů, konceptů, metod a teorií, aby následně své poznatky prostě spojily v jeden celek, je jindy též označována jako multidisciplinarita [Max-Neef 2005]. Z latinského multus neboli mnohý se zrodilo označení přístupu, v němž se jednotlivá odborná východiska staví jedno vedle druhého. Důsledkem takové spolupráce je kumulace, prosté nahromadění poznatků, nikoliv jejich propojení. Cokoliv, k čemu přidáme předponu multi-, je tedy pouze sběrnou různých částí, které vedle sebe existují, ale dosud nemůžeme mluvit o syntéze.

Druhou, nejobvyklejší variantou v praxi je dělba práce mezi naukami při zkoumání společného problému. Koordinace a kooperace se zde týká i vstupů a výstupů, ale neovlivňuje vnitřní složky a strukturu vědních analýz. Nemění výzkumné procesy jako takové [Baumgärtner 2008].

Konečně třetí podobou interdisciplinarity, totiž tou, která je pro dnešní společnost nejhůře dosažitelná, je plnohodnotný vědní obor, který se vymezuje vůči úzké specializaci a autenticky kombinuje metodologii, terminologii a paradigmata jiných, samostatných věd. Takový revoluční obor, který zcela přesahuje dnešní kuhnovskou „normální vědu“, dosud vytvořen nebyl. Je otázkou, zda vůbec vzniknout může, nebot' „tato forma plně integrované interdisciplinární spolupráce vyžaduje od všech vědců schopnost překročit hranice svých vlastních oborü“ [Baumgärtner 2008: 386]. Zdá se, že některé koncepty vidění světa cele propojit nelze, avšak všechny by měly dostat slovo při debatě nad společným tématem. Tento problém připomíná otázku dosažitelnosti trvale udržitelného rozvoje, který - stejně jako interdisciplinarita, z latinského inter (mezi), tedy mezní, hraniční - vyžaduje radikální přerod existujících vzorců.

Tím se dostáváme k podstatě naší druhé teze, totiž požadavku transdisciplinarity. Latinské trans neboli napříč napovídá, že půjde o přístup průřezový, protínající. Jde napříč různými oblastmi lidského poznání a vědy s tím, že nestačí poznatky kumulovat, ale je nutné mezi nimi hledat souvislosti, anomálie i shody. Transdisciplinarita podle Baumgärtnera je způsobem propojení vědy a společnosti. Nemluvíme tu o novém převratném vědeckém projektu, nýbrž o obnoveném procesu či způsobu vidění. Specializace se 
z transdisciplinární perspektivy nejeví jako škodlivá, ale důraz je kladen na vědomí této specializace. Výseky reality jsou studovány odděleně, ale zároveň programově v zájmu lepšího porozumění celku.

V dnešní akademické praxi se i transdiciplinarita stává nadějí, která je prozatím nenaplněná. Stojíme před konfliktem návratu $\mathrm{k}$ mytickému vidění světa na straně jedné (je transdisciplinarita další z velkých metanarací?) a lpění na tradičních vědeckých metodách a definicích na straně druhé (lze postupně stírat hranice mezi společenskými a prírodními vědami?).

I přes nesnadnost dosažení transdisciplinární mety stojí za to se o ni pokusit. V opačném př́padě hrozí apatie vůči světu mimo zdi vědcovy slonovinové věže - selhání, před kterým konference Naše společná přítomnost i příspěvky shromážděné v této publikaci chtějí varovat. Slovy německého filosofa Vittoria Hösleho:

Tato lhostejnost, tato neschopnost propojovat to, čím se „vědecky“ zabýváme, se světem, ve kterém žijeme, je nejhlubším důvodem pro vnitřní nespokojenost většiny humanitních vědců a jejich pocit odcizení a emocionální vyprahlosti, kterou veškerá čilá podnikavost a patos objektivní vědeckosti nemůže dlouhodobě zakrývat. [Hösle 1994: 21]

\section{Teze 3. Kulturní ekologie jako vztah mezi člověkem a prostředím (přírodou) a nutnost jejich reflexe v kultuře}

Zakladatelská teze sensu Julian Steward, totiž že existuje nepopiratelný vliv př́rodního prostředí na sociální organizaci a instituce společnosti a že změna prrírodního prostředí se projevuje na všech úrovních organizace společnosti, je stále živá a paradoxně její důsledky pro současnou post-moderní společnost stále rostou. Samozřejmě je otázka studia, do jaké míry, kde nejvíce, $v$ jaké formě atd. se vliv přírodního prostředí odráží v sociální organizaci a institucích společnosti. I velké moderní společnosti žijí v nějakých konkrétních krajinách, i ony jsou závislé na velkých přírodních silách biosféry a přes veškeré zdání na substituci potravin, energie a informací na globálním trhu. Tato zakladatelská teze má současné post-moderní konsekvence:

- ekologickou: Kulturní ekologie se zabývá vztahem člověka k prostředí adaptačním mechanismem kultury.

- environmentální: Kulturní ekologie je reakcí na globální ekologickou krizi.

Z toho ovšem vyplývá teze nejdůležitější pro kulturní ekologii, vycházející ze Stewardova vymezení kulturní změny: Jestliže se změna prostředí neprojeví včas na jednotlivých úrovních organizace a institucích společnosti, jakou budoucnost tato společnost má?

Věda může dávat sebepromyšlenější postupy, návody, opírat se o sebepřesnější data, ale společnost vůbec nemusí tuto skutečnost přijímat. Teprve kultura jako adaptační mechanismus, jako specifický zpo̊sob existence člověka v biosféře, může a musí ohromující signály o změnách prostředí, projevující se dnes ve srozumitelných formách jako například změny krajiny, pochopit a reagovat na ně. Jiný mechanismus jako lidská společnost pro změny sociální organizace a institucí nemáme, zde nám geny mnoho nepomohou.

Třetí tezí tedy poukazujeme na omezený dopad vědy, nejsou-li její výsledky paralelně sledovány v projevech kultury. Slovy britského environmentálního etika Robina Attfielda: 
Současné problémy vyžadují víc než jen teorii, mají-li být vyřešeny, a také víc než přeorientování a osobní nasazení jedince. Řešení budou muset být řešeními koordinovanými; tím pádem vstupují do hry politické a často mezinárodní akce a opatření. [Attfield 1991: xviii]

Kulturní ekologie se může sama o sobě jen sotva proměnit v kulturní (v širším smyslu toho slova) iniciativu, avšak může svými poznatky společenskou proměnu podpořit. A také by to udělat měla, nechce-li zůstat uvězněna na bezpečné půdě akademické neutrality, spokojená se stávajícím stavem a jeho popisem. Podle Otto C. Scharmera z Massachusetts Institute of Technology patří k bariérám otevřeného myšlení neschopnost rozpoznat to, co ve skutečnosti vidíme, vyjádřit svůj názor, vyvarovat se rozporů mezi slovem a reálnou akcí a následně své vlastní jednání posoudit [Scharmer 2009]. Změny, jimiž náš svět v důsledku zásahů do prostředí prochází, musejí být rozeznány a pojmenovány. To je úkolem vědy. Reakce a její reflexe už náležejí i do dalších oblastí lidské činnosti, avšak bez nich „vidění“ a „rozpoznání“ k výsledku - změně - nevedou.

\section{Teze 4. Přítomné problémy kulturní ekologie}

Zdá se, že reflexí společnosti a přírody ve smyslu ekologických podmínek prostředí se kulturní ekologie otevírá přítomným, současným problémům. Jsou to problémy globální, jak je rádi nazýváme, nebot zasahují euro-americkou civilizaci a přelévají se do Asie, Latinské Ameriky a Afriky. Podíváme-li se na prrítomné problémy z hlediska „účastníků“, nemůžeme se vyhnout pojmům:

- Společnost (jedinec, skupina, instituce)

- Prostředí (příroda, město, kultura)

- Krize (společnosti, prostředí)

- Změny (hodnot, systému, prostředí, společnosti)

- Management

Tyto pojmy jsou seřazeny tak, že Společnost a Prostředí jsou aktéři, Krize je nežádoucí stav jejich vzájemných interakcí, Změny a Management jsou nabízená řešení.

Úsilí kulturní ekologie rozbít dichotomii mezi přírodním a umělým, př́padně lidským a mimo-lidským, je dobře vidět na kategorii Prostředí. Společnost jako aktér nepřekvapí, logické je i zahrnutí mikro-, meso- a makro-perspektivy, tedy individuálních, institucionálních a celospolečenských otázek. Důležitá je ale potřeba věnovat se paralelně interakci člověka a města, člověka a kulturní krajiny, člověka a divočiny. Každý z uvedených vztahů (a jejich výčet je pouze ilustrativní) je odlišného charakteru a má jiné dopady na zúčastněné strany, jinak vyhlížejí krize těchto vztahů, ale společný je pro ně aktivní lidský faktor.

Samotné postavení kulturní ekologie mezi těmito „účastníky“ je poněkud paradoxní. Nezaujímá místo vědecké analýzy, k tomu slouží daleko lépe specializované biologické disciplíny, které dokáží vyčíslit zdravotní parametry životního prostředí. Na druhé straně kulturní ekologie nemůže nahradit psychologické, sociologické a ekonomické analýzy společnosti. Právě kultura je nejspíš jediným převodníkem a zprostředkovatelem po- 
znatků výše zmíněných věd do společnosti, aby vůbec mohlo docházet $\mathrm{k}$ jejím změnám v duchu zakladatelské teze kulturní ekologie.

Je to zřejmě kulturní ekologie, která by měla dát odpovědi na otázky mezi využitím a ochranou přírodních, lidských a kulturních zdrojů, či alespoň napomoci při správném formulování otázek, které jsou nyní roztř̌ištěny mezi parciální zájmy úzce profilovaných nauk.

Prostor a čas, v jejichž intencích je dnes třeba o světě uvažovat, jsou mnohem rozsáhlejší než před 100 či 500 lety. Vzájemná provázanost složek je čím dál viditelnější a specializovaná věda nemá nástroje, pomocí nichž by mohla zacházet s výzvami, před kterými člověk v globalizovaném, přelidněném a znečištěném světě stojí.

Australská ekofeministka Val Plumwood k tomu ironicky podotýká:

Věda nás spasí, ale jen za předpokladu, že neztratíme trpělivost či víru v technorozum a odhodlání pokračovat v započatém kurzu, at se jeví jakkoliv nestabilně. Toto je vědecké tvrzení srovnatelné s přesvědčením, že vše bude dobré, budou-li pravidla trhu uplatňována s ještě větší přísností. [Plumwood 2002: 6]

Jak už bylo naznačeno ve druhé tezi, integraci přírodních a společenských věd, po kterých vizionářští myslitelé volají již několik desetiletí, se nedaří uskutečnit. Nastavení mysli západního člověka, kulturně „cvičeného“ k členění žité zkušenosti na dílčí celky, je zakořeněno velice hluboko. Slovy holandského kulturologa Geerta Hofstede: „(Kultura je) kolektivním programováním mysli, které odlišuje členy jedné skupiny či kategorie od druhé“ [Hofstede 1994: 5].

V tuto chvíli je lidská mysl v západní kultuře naprogramována tak, že oslabuje udržitelnost svých vlastních výsledků. Dostali jsme se do fáze, kdy je jakákoliv snaha oddělit od sebe celosvětové problémy ekonomického, politického, kulturního, filosofického či ekologického charakteru nutně odsouzena k reduktivnosti. Dílčí řešení komplexního problému není nikdy uspokojivé. Komplexní, stejného druhu a stejně úspěšné, jaké přinášejí specializace, zase nemáme po ruce.

Dovolme si zde obsáhlejší citace z práce německého filosofa Klause Meyer-Abicha.

Dostali jsme se do krize, která je do značné míry krizí našeho začlenění do celku, jehož jsme součástí. V ideálu vzájemného propojení politiky a pravdy však spočívá životní síla, která může zachránit i průmyslovou společnost. ... Vztahovat k sobě politiku a pravdu nikoliv jako danosti, nýbrž jako procesy, to vyžaduje určitou kulturu, jíž se nám prozatím nedostává. Důkladně se zabýváme jednotlivými kroky, až ztrácíme ze zřetele cestu. ... Holistické myšlení v návaznosti na ekologickou a společenskou odpovědnost je $k$ tomu vodítkem. Umožňuje vědu pro budoucnost a budoucnost pro průmyslovou společnost. V něm dokonce spočívá nová víra ve vědu. [Meyer-Abich 1988: 172]

Téměř čtvrt století stará naděje není dnes o nic méně aktuální. Nežijeme již v průmyslové společnosti, vědecko-technický vývoj dospěl do nových fází, ale Společnost, Prostředí, Krize, Změny a Management zůstávají účastníky dialogu, který snad kulturní ekologie může usnadňovat. 
Kulturní ekologie stojí z hlediska společnosti mezi institucemi „moderní doby“ rozdělujícími svět na přesně určené kompetence, stejně jako je tomu u dobře fungujícího výrobního pásu. Tyto instituce, jak vidíme z jejich neschopnosti pojmenovat a řešit problémy komplexně, jsou přes své označení „moderni““ vlastně zastaralé. Na druhé straně stojí propojený svět - přirozený svět člověka, s postmoderní snahou o rehabilitaci subjektivní činnosti jedince, jeho identity a významu.

Z hlediska př́rody (ekologie) řeší kulturní a sociální ekologie nikoli monolog - diktát člověka a nároky na uspokojení výlučně antropocentrického příběhu.

Z hlediska člověka řeší kulturní a sociální ekologie nikoli monolog - diktát biologických zákonů od genu přes biosféru a Gaiu bez možnosti cokoli ovlivnit s pohodlnou nezodpovědností, že nemůžeme jako společnost nic dělat proti obrovským prŕrodním silám Země a Vesmíru.

Dialog mezi člověkem a prostředím (přírodou) je něčím, co vyžaduje otevřenost mnohem méně zjednodušujícím přístupům. „Náš problém nespočívá primárně ve znalostech či technologii; jde o rozvoj environmentální kultury." [Plumwood 2002: 3] V centru zájmu stojí otázka, kterou nelze přejít, protože se vynořuje při hledání řešení kteréhokoliv současného problému (sociálního, ekonomického, politického, etického). Životní prostředí, respektive jeho omezenost, je ústředním tématem pro dnešního člověka. „Veškeré lidstvo a mnoho dalších druhů a ekosystémů, které sdílejí planetu Zemi, se potýká s hrozbami pro budoucí životaschopnost Civilizace." [Katzenstein 2010: 37]

Je to transdisciplinární dialog, nikoliv definitivní odpověd, který ve veřejném akademickém prostoru chybí. Kulturní ekologie, pokud chce být úspěšná a potřebná, nabízí mnohdy neúspěšný, rozpačitý, ale přece jen počínající dialog člověka a prostředí. Máme na něj dost času? To je právě otázka přítomnosti.

\section{Poděkování}

Jan Vávra děkuje za podporu poskytnutou formou účelového stipendia Filozofické fakultě Univerzity Karlovy v Praze. Autoři děkují oběma anonymním recenzentům za jejich užitečné připomínky a opravy.

\section{LITERATURA}

Adler, Emanuel. 2010. „Europe As a Civilizational Community of Practice.“ Pp. 67-90 in Peter J. Katzenstein (ed.). Civilizations in World Politics: Plural and Pluralist Perspectives. London, New York: Routledge.

Attfield, Robin. 1991. The Ethics of Environmental Concern. Athens, London: The University of Georgia Press.

Bateson, Gregory. 1973. Steps to an Ecology of Mind. London: Paladin.

Baumgärtner, Stefan, Christian Becker, Karin Frank, Birgit Müller, Martin Quaas. 2008. „Relating the philosophy and practice of ecological economics: The role of concepts, models, and case studies in inter- and transdisciplinary sustainability research." Ecological Economics 67: 384-393. 
Biehl, Janet. 2003. Pozvání do sociální ekologie. Praha: Subverze.

Blažek, Bohuslav. 1998. Venkov, města, media. Praha: Sociologické nakladatelství.

Bookchin, Murray G. 2005. The Ecology of Freedom: The Emergence and Dissolution of Hierarchy. Oakland: AK Press.

Catton, William Jr. R., Riley E. Dunlap. 1980. „A New Ecological Paradigma for Post-Exuberant Sociology.“ American Behavioral Scientist 24 (1): 15-47.

Dunlap, Riley E., William R. Catton Jr. 1979. „Environmental Sociology.“ Annual Review of Sociology 5: $243-273$.

Durkheim, Émile. 1966. The Rules of Sociological Method. New York, London: The Free Press, Collier-MacMillan Ltd.

Durkheim, Émile. 2008. „Course in Social Science - Inaugural Lecture.“ Organization \& Environment 21 (2): 188-204.

E-Architekt. 2004. „Rozhovor s Bohuslavem Blažkem nejen o sociální ekologii (8. 11. 2004).“ [online] Praha: E-Architekt. [cit. 23. 4. 2011] Dostupný z: http://www.e-architekt.cz/print.php?PId=953.

Finke, Peter. 2005. Die Ökologie des Wissens. Exkursionen in eine gefährdete Landschaft. Freiburg, München: Alber.

Hawley, Amos H. 1944. „Ecology and human ecology.“ Social Forces 22 (4): 398-405.

Hofstede, Geert. 1994. Cultures and Organizations. Hammersmith, London: Harper-Collins.

Hösle, Vittorio. 1994. Die Krise der Gegenwart und die Verantwortung der Philosophie. München: Beck.

Katzenstein, Peter J. 2010. „A World of Plural and Pluralist Civilizations: Multiple Actors, Traditions and Practices. “ Pp. 1-40 in Peter J. Katzenstein (ed.). Civilizations in World Politics: Plural and Pluralist Perspectives. London, New York: Routledge.

Keller, Jan. 1997. Sociologie a ekologie. Praha: Sociologické nakladatelství.

Keller, Jan. 1998. Naše cesta do prvohor. O povaze automobilové kultury. Praha: Sociologické nakladatelství.

Klaus, Václav. 2010. „Novoroční projev prezidenta republiky.“ [online] [cit. 30. 6. 2011] Dostupný z: http://www.klaus.cz/clanky/2491.

Lapka, Miloslav. 2008. Úvod do sociologie krajiny. Praha: Univerzita Karlova v Praze - Nakladatelství Karolinum.

Lapka, Miloslav, Miroslav Gottlieb. 2000. Rolník a krajina. Kapitoly ze života soukromých rolníků. Praha: Sociologické nakladatelství.

Lapka, Miloslav, Jan Vávra, Zdenka Sokolíčková. 2011. „Kulturní a sociální ekologie - co může studentům nabídnout?" Pp. 54-62 in Ivo Machar (ed.). Vzdělávání v ochraně př́rody a krajiny. Brno: CZ-IALE.

Librová, Hana. 1987. Sociální potřeba a hodnota krajiny. Brno: Universita J. E. Purkyně.

Librová, Hana. 1994. Pestří a zelení: Kapitoly o dobrovolné skromnosti. Brno: Veronica, Hnutí Duha.

Max-Neef, Manfred A. 2005. „Foundations of Transdisciplinarity.“ Ecological Economics 53: 5-16.

McKenzie, Roderick D. 1924. „The Ecological Approach to the Study of Human Community." American Journal of Sociology 30 (3): 287-301.

Musil, Jiří. 1991. „Nové vymezení sociální ekologie.“ Sociologický časopis 27 (1): 69-89.

Netting, Robert McC. 1968. Hill Farmers of Nigeria: Cultural Ecology of the Kofyar of the Jos Plateau. Seattle: University of Washington Press.

Ortová, Jitka. 1999. Kapitoly z kulturní ekologie. Praha: Univerzita Karlova v Praze - Nakladatelství Karolinum.

Meyer-Abich, Klaus M. 1988. Wissenschaft für die Zukunft: Holistisches Denken in ökologischer und gesellschaftlicher Verantwortung. München: Beck.

Morgan, Lewis Henry. 1954. Pravěká společnost neboli Výzkumy o průběhu lidského pokroku od divošství přes barbarství k civilisaci. Praha: Československá Akademie věd.

Park, Robert Ezra. 1915. „Suggestions for the Investigation of Human Behavior in the City Environment.“ American Journal of Sociology 20 (5): 577-612.

Park, Robert Ezra. 1936. „Human ecology.“ American Journal of Sociology 42 (1): 1-15.

Park, Robert Ezra, Ernest W. Burgess, Roderick D. McKenzie. 1925. The City. Chicago: The University of Chicago Press. 
Plumwood, Val. 2002. Environmental Culture: The Crisis of Reason. London, New York: Routledge.

Rosa, Eugene A., Lauren Richter. 2008. „Durkheim on the Environment. Ex Libris or Ex Cathedra? Introduction to Inaugural Lecture to a Course in Social Science, 1887-1888. “ Organization \& Environment 21 (2): 182-187.

Rynda, Ivan. 2006. „Trvale udržitelný rozvoj a vzdělávání“. Pp. 231-236 in Jana Dlouhá, Jiří Dlouhý, Václav Mezřický (eds.). Globalizace a globální problémy. Sborník textů k celouniverzitnímu kurzu „Globalizace a globální problémy" 2005-2007. Praha: Univerzita Karlova v Praze - Centrum pro otázky životního prostředí.

Scharmer, Otto C. 2009. Theory U: Leading from the Future as It Emerges. San Francisco: Berrett-Koehler. Soukup, Václav. 2010. „Culturology: A New Synthesis.“ Anthropologia Integra 1 (1): 29-37.

Soukup, Václav. 2011. Antropologie. Teorie člověka a kultury. Praha: Portál.

Steward, Julian. 1950. „Area Research: Theory and Practice.“ Social Science Research Council Bulletin 63: $1-164$.

Steward, Julian. 1951. „Levels of Sociocultural Integration: An Operational Concept.“ Southwestern Journal of Anthropology 7: 374-390.

Steward, Julian. 1955. Theory of Culture Change: The Methodology of Multilinear Evolution. Urbana: University of Illinois Press.

United Nations. 1987. Our Common Future: Report of the World Commission on Environment and Development.

White, Leslie Alvin. 1959. The Evolution of Culture: The Development of Culture to the Fall of Rome. New York: McGraw-Hill.

\section{SUMMARY}

Today, the character and role of cultural ecology as a scientific discipline reflecting the relationship between human society and natural environment is questioned under the light of contemporary global environmental and societal issues. The introductory article of the initiators and organizers of the conference entitled Our Common Present completes three aims.

First of all, it comments on the original focus of the discipline and the shift that it underwent after being established in the 1950s by Julian Steward. The fact that environmental circumstances influence institutions and societal order is still valid, yet by no means is the importance of the impact of human society onto natural environment less significant.

In the second part, the article summarizes historical stages and diverging concepts that marked the evolution of the discipline. The difference between cultural and social ecology, and the living heritage of Murray Bookchin, Chicago school and environmental sociology are discussed. The overview concludes with an informative section about Czech academic institutions active in the field of cultural ecology. Reflection on the responsibility of cultural ecologists, as revealed by Bohuslav Blažek, is underlined.

The link between the academic sphere and urgent issues of nowadays, or more precisely, the need to establish it, triggers the formulation of five constitutive principles of today's cultural ecology. These include: 1) focus on present times instead of escapes into the past or the future, 2) transdisciplinarity, 3) reflection on the society-environment relationship through culture, 4) dealing with concrete global problems, and 5) dialogue between man (society) and environment (nature).

Complex societal reality of the 21 st century is calling for approaches that avoid plain reductionism. The task that cultural ecology is facing at the moment is to clarify what issues it can address in a way inaccessible to other, highly specialized scientific disciplines. The ability to prove its potential for a better understanding of environmental and societal processes that determine our times will be crucial for its future course. 